\title{
Exploring Self-Concept on Young Prisoners Using An Appreciative Inquiry Approach
}

\author{
Andromeda, Yogi Swaraswati \& Woro Apriliana Sari \\ State University of Semarang \\ andromeda@mail.unnes.ac.id
}

\begin{abstract}
Based on the importance of young inmates' self-concept for the success of the reintegration process, this study aims to explore self-concept with other approaches. A qualitative descriptive method was employed using the four-stage Appreciative Inquiry approach. 9 young prisoners participated in 2 focus groups. Thematic analysis was employed to identify empirical codes and examine relationships within and across the data. The findings in this study are themes that appear in four stage. The "Discovery" stage is the most difficult stage of the other four stages. Getting participants to believe in researchers is not easy. The Appreciative Inquiry process can not be applied in a formal format to young prisoners. They like something that relaxes, flows, and does not make them feel intimidated. Different educational and social backgrounds among them are a bit of a constraint in the implementation of this process. The differences are what caused the gap among the participants.
\end{abstract}

Keywords : self-concept, young prisoners, appreciative inquiry

\section{INTRODUCTION}

Adolescence is the period in life of heightened "storm and stress" resulting in conflicts with parents, mood disruptions as well as reckless, norm-breaking, and antisocial risk behavior (Arnett, 1999). Especially young men are in danger of commiting crimes (Moffitt, 1993) due to several reasons like testing a possible identity or depending on peer influences ( Dishion, McCord, \& Poulin, 1999 ). Negative behaviors of teens that may result in crimes or legal action, frequently causes widespread problems in comunities. (https://www.rand.org/topics/juveniledelinquency.html). Numerous psychological investigations have attempted to explain juvenile deliquency and ways of rehabilitating young offenders with reference to various personality variables such as intellectual capacity, moral reasoning, maturity, and self-concept, as well as to previous deviant behavior, including aggressive, antisocial, or suicidal behavior in childhood (Otto and Dalbert, 2005).

Psychologists, sociologists and criminologists the world over have long debated the various causes of delinquency. Theses focuses on some of the causes the have been and are considered viable from a theoretical and conceptual framework of the study. Some of the theorists point out family problems includes parental attitudes, monitoring, family structure, family organization and disorganization etc. Others indicate socio-economic conditions (especially poverty) are of prime importance in a young person's life. There is also the factor of peer influences. Young people are especially vulnerable in their early teen years and subject to a great deal of peer pressure to conform to certain values, norms and behaviors. Delinquency continues to be a salient topic today and we continue to search for answers to its causative factors. It is clear from the beginning of the introduction that not one but a combination of factors are the strongest predictor of delinquent behavior. Like familial relationships combined with an association with delinquent peers offers the highest predictor for delinquency although it might be tempting to assume that parental abuse of their children would be the conclusion here in terms of familial influence, the authors note this is not necessarily the case. There are parents who give poor directions to children, fail to structure their behavior and do not reward or punish appropriately. Our prediction was that the highest levels of antisocial behavior would occur where poor attachment between parent and child was combined with poor controls". (Hoge et al., 1994; Nisar, et al, 2015). The juvenile delinquency phenomenon shows signs of lack or no conformity to social norms and the majority of criminal cases commited by adolescence. The highest number of crime acts existed at 15 to 19 years and after 22 years will decrease. (Mu'tadin, 2002).

Semarang as one of the major cities in Indonesia, also noted many cases of juvenile delinquency that lead to crime, ranging from brawl between students, free sex, and drugs. Flashbacks of some cases that occurred, for example are brawl between students triggered by an attack against students SMK 4 Semarang (occurred on 18 September 2013). Another case in the case of drug abuse, BNN data said, during 2013 recorded $22 \%$ of Indonesian adolescents use drugs. While in Central Java, there are as many as 493 thousand people who use drugs $(2,11 \%$ of whom are teenagers).

The case of juvenile delinquency that needs to be a serious concern for families, communities, and governments in addition to fighting and drugs is free sex and pornography. Free sex behavior affects infectious diseases such as HIV / AIDS, with 400 cases in Central Java (70\% spread in Semarang). BKKBN data there are 2.4 million cases of abortion conducted by adolescents (junior and senior high school students). In 2016, BKKBN recorded that $8.3 \%$ of adolescent boys and $1 \%$ of adolescent girls actively engage in extramarital sex. Data PKBI Java period 2010-2014 (pkbijateng.or.id, 2016), there are 65 to 85 girls at the age of 15 to 18 years of unintended pregnancy (KTD).

Teenagers who are in conflict with the law and sentenced to imprisonment, then placed in Penitentiary. One of the sub units in LAPAS Class I Semarang which is tasked to conduct guidance on the inmates is the section of Community Guidance. Based on the results of 
interviews with the Community Guidance on January 14, 2017, it is known that inmates in LAPAS Class I Semarang still need psychological assistance, especially related to the readiness of prisoners in the process of reintegration into the community. In fact, there is a separate problem that concerns the restoration of his psychological condition. The bad stigma of society against inmates, affect their self-concept. Behind the joy of freedom, guilt and inferior feelings dominate their psychological state. This study wanted to know the selfconcept of prisoners in the pre-reintegration period.

\section{METHOD}

Using qualitative method with Appreciative Inquiry approach, this research explored self-concept on young prisoners in pre-reintegration stage. A qualitative descriptive method was employed using the four stage Appreciative Inquiry approach (Sidebotham; Fenwick; Rath; and Gamble, 2015). Appreciative Inquiry is an organisational development process where individuals are guided to adopt positive chains of thought when considering organisational change. Appreciative Inquiry is based on theories of social construction in which interpretation of reality is crucial to social action (Whitney and Cooperrider, 2005). Unlike other approaches to reserach that traditionally use a problem solving approach, Appreciative Inquiry actively promotes positive thinking and celebrates success, achievement, and what is already working (Carter, 2006). The process encourages participants to reflect not only on "what is" but to envisage "what could be".

\subsection{Participants}

Participants were selected by age (18 to 21 years). 9 adolescent inmates who had filled informed consent were willing to be involved in the study. They are divided into 2 groups.

1.2. Data Collection

Semi-structured focus group discussions were used in preference to individual interviews in order to increase positive value of participants. The focus group questions were designed around the four Appreciative Inquiry stages of (1) Discovery; (2) Dream; (3) Design; and (4) Destiny.

The first stage, Discovery involved determining the best of what is. Participants are asked to focus on experiences of best practices, positive moments, and successful processes. Then, participants were asked to envisage positive possibilities on Dream stage. The third or Design stage involved creating the structure, processes, and relationships that would best support "the dream". Finally, the Destiny stage involved developing a plan for implementation.

\subsection{Data Analysis}

A model of iterative thematic analysis was employed to identify empirical codes and further examine relationships to find meaning within and across the data (Gibson and Brown, 2009). Firstly the focus group tapes were listened to several times by the key investigators independently and then together prior to formal coding. The researchers independently read and re-read the transcripts and field notes to gain an overall impresion of the data. Data was then coded and sorted into themes within each phase of the Appreciative Inquiry approach. Used more than one analyst provided an opportunity to assess the reliability of the coding with respect to major themes and issues. The categories were then collated and individually discussed by the whole team. Where disagreement occurred the researchers returned to the data to re-examine and recode until congruence could be achieved.

\section{FINDINGS}

\subsection{Discovery}

During this first phase, participants were asked to express positive experiences while in the Penitentiary (LP) especially after getting sufficient correctional guidance.

3.1.1. Meet a friend who has the same fate

$80 \%$ of participants were shocked when they first underwent periods of detention. Trying to accept and be entertained for meeting with friends who are in the same boat.

3.1.2. Connection with and support from each other

Meet with friends who have the same fate, then make them feel connected to each other. Support from the environment in Penitentiary also makes them stronger and more accepting of life's reality. Mutually telling how they can be punished, learning from the mistakes of self and others is also important.

3.1.3. Time to improve

8 of 9 participants thought that the period of detention was a time of self-improvement. The rest still think that he was punished not because of his mistake. That is, the majority of participants are able to positively interpret their experience in the Penitentiary.

\subsection{Dream}

Following the Discovery stage, participants were asked to imagine and describe what their perfect role, within the organisation, would be if "anything" were possible. With prompting participants identified two "dream" themes. However these were in essence somewhat contradictory.

3.2.1. Continue school or work

4 of 9 participants wanted to go to school or get a job after free. They feel that the period of detention makes what they once planned to be delayed.

3.2.2. Gathering with family All participants miss family and home. The fact that their meeting with the family is so limited makes them want to be free to get together with their parents and relatives.

3.2.3. Being a new man, in a new place

1 of 9 participants stated that he wanted to go far from this city to be able to forget the bad experience he had ever experienced. Unpleasant stimuli make participants afraid to do something. So, moving to another city is considered as the right decision to not always remember the experience that made him shy and uncomfortable.

3.3. Design

In the Design stage, participants were asked to think about what structures, processes, and relationships would be required to support "the 
dream”. All participants recognised there was a need to take "positive action" to achieve change.

3.3.1. Must have the power to resist temptation from within

3 of 9 participants thought that what they are experiencing now is due to their inability to control themselves. Self-control is needed in determining individual behavior.

3.3.2. Hard work

They are aware of a negative assessment of the social environment. It takes will and hard work to change fate and not repeat the same mistakes.Harus punya kekuatan melawan godaan dari dalam diri

3.4. Destiny

3.4.1. It is not easy to start againFacing the bad stigma of the social environment will be an obstacle for the participants to go through reintegration. Some of them are quite confident, but some are feeling inferior and anxious to return to the environment.

3.4.2. Traces of the past can not be erased, must learn from it.

Trying to learn from such an ugly experience. Finding an identity as an adult person becomes a challenge for them. It takes great support from the family and the environment.

\section{DISCUSSION AND CONCLUSION}

Unlike traditional approaches, the focus of appreciative inquiry is to learn about the strenghts and successes of people who are interested in sharing their strength and the stories of triumph related to their lives, communities, and organisations, which it is hoped will provide a new vision for the future (Nyaupane and Poudel, 2012). However, this study encountered a number of obstacles, not easy to encourage participants to engage and speak in front of many members of the group. Only 2 of 9 participants are cooperative and easily follow all stages of Appreciative Inquiry. To overcome that difficulty, researchers build relationships with better participants through some fun game activities.

Whatever the inquiry method, participants take the lead role. The role of researcher is to listen, question, cue, guide , and encourage the participants to make success stories more descriptive and interesting (Watkins and Mohr, 2001). In other words, the participants in the Appreciative Inquiry process are coresearchers engaged in bringing about change through interaction with others.

The "Discovery" stage is the most difficult stage of the other four stages. Getting participants to believe in researchers is not easy. The first day of the study, can not reach all stages in Appreciative Inquiry. At the "discovery" stage, almost all participants have difficulty expressing the positive meaning of their experiences so far. Frequently faced with negative labels because of the mistakes that participants have made, making them less able to appreciate the positive things they achieve.
The second day of the study, participants are more comfortable so that the stage of dream, design, and destiny can be done quite well. The findings during the study, the Appreciative Inquiry process can not be applied in a formal format to juvenile inmates. They like something that relaxes, flows, and does not make them feel intimidated. As stated by Nyaupane and Poudel, (2012) that "the appreciative inquiry process can be formal or informal, fast or slow, and may include all the employees of an organization, or only the representatives of stakeholders.

From the Appreciative Inquiry process conducted for 2 days, the benefits that participants get are learning from each other's experiences and how other participants interpret them. Different educational and social backgrounds among them are a bit of a constraint in the implementation of this process. The differences are what caused the gap among the participants. Some are active, but others need to be encouraged to be more involved.

The success of the Appreciative Inquiry approach reliess on the understanding of social relationships, social conflicts, and a broad knowledge of the sociocultural, historical, political, and economic underpinnings of a community (Messerschmidt, 2008). Therefore, before conducting research, researchers need to explore in depth about the case history, educational and social background and their daily habits while in detention (Penitentiary). All of it is helpful to create trust from participants to researchers.

Another finding is, still among the participants who have low self-esteem. They assume that what they have done will hinder the reintegration process once free. Confidence will affect their self-concept. And, negative self-concept can predict the possibility of re-occurring behavioral disorders in individuals. "Numerous psychological investigations have attempted to explain juvenile deliquency and ways of rehabilitating young offenders with reference to various personality variables such as intellectual capacity, moral reasoning, maturity, and self-concept, as well as to previous deviant behavior, including aggressive, antisocial, or suicidal behavior in childhood" (Nisar, et al, 2015).

\section{LIMITATION OF STUDY}

Appreciative Inquiry should not be a magical reserach tool. There are many challenges that we faced during this research, and they should be seriously addressed when applying the appreciative inquiry approach. Appreciative Inquiry can be no more than a daydream or a false hope if the process is not carefully followed (Nyaupane and Poudel, 2012). Similarly to this study, many challenges that researchers face. Prisoners have been frequently involved in research activities so that they tend to persist and assume that our research is similar to others and will not have any positive impact on their psychology. 


\section{REFERENCES}

Arnett, J. J. (1999). Adolescent storm and stress, reconsidered. American Psychologist, 54, 317-326.

Carter B. (2006). 'One expertise among many' - working appreciative to make miracles instead of finding problems: using appreciative inquiry as a way of reframing research. J Res Nurs 11 (1), 48-63.

Dishion, T. J., McCord, J., \& Poulin, F. (1999). When interventions harm: Peer groups and problem behavior. American Psychologist, 54, 755-764.

Gibson, W \& Brown, A. (2009). Working with qualitative data, London : Sage.

Hoge, R. D., Andrews, D. A., \& Leschied, A. W. (1994). Test of three hypotheses regarding the predictors of delinquency. Journal of Abnormal Psychology, 22 (5), 547-557.

Messerschmidt, D. (2008). Evaluating appreciative inquiry as an organizational transformation tool: an assesment from Nepal. Human Organization, 67 (4), 454-468.

Moffitt, T. E. (1993). Adolescence-limited and life-coursepersistent antisocial behavior: A developmental taxonomy. Psychological Review, 100, 674-701.

Mu'tadin. 2002. Remaja dan Rokok. http//:www.epsikologi.com. (diunduh 6 Maret 2017).

Nisar, M., Ullah, S., Ali, M., \& Alam, S. (2015). Juvenile delinquency : The influence of family, peer, and economic factors on juvenile delinquents. Applied Science Reports. 9 (1), 37-48.

Nyaupane, G. P \& Poudel, S. (2012). Application of appreciative inquiry in tourism research in rural communities. Tourism Management (33), 978-987.

Otto, K \& Dalbert, C. (2005). Belief in a just world and its functions for young prisoners. Journal of Research in Personality, 39, 559-573.

PKBI Jateng. 2016. Data Kenakalan Remaja. http//:www.pkbijateng.or.id (diunduh 6 Maret 2017).

Sidebotham, M., Fenwick, J., Rath, S., \& Gamble, J. (2015). Midwives' perceptions of their role within the context of maternity service reform: An Appreciative Inquiry. Women and Birth (389).

Watkins, J. M \& Mohr, B. J. (2001). Apprecitive inquiry : Change at the speed of imagination. San Fransisco, CA: Jossey-Bass/Pfeiffer. 